\title{
文字連鎖を用いた複合語同音異義語誤りの検出手法と光の評価
}

\author{
奥 雅 博 ${ }^{\dagger}$ 松岡 浩司 ${ }^{\dagger}$
}

本論文では，文字連鎖を用いた複合語同音異義語誤りの検出手法とその評価について 述べる。ワードプロセッサによって作成された日本語文書には，変換誤りに起因する 同音異義語䛊りが生じやすい，同音異義語誤りは，同じ読みの単語を誤った単語へと 変換してしまう䛊りである。このため，推敲支援システムにおいて同音異義語愦りを 検出する機能を実現することは重要な課題の 1 つとなっている。我々は，意味的制約 に基づく複合語同音異義語䛊りの検出／訂正支援手法を提案した. しかし，この手法 においてもいくつかの短所が存在する。本論文では，これらの短所を補うための手法 として，文字連鎖を䛊り検出知識として用いた複合語同音異義語誤りの検出手法につ いて述べる．文字連鎖は，既存の文書を解析することなしに容易に収集することがで きる，また，本手法は文字連鎖のみを用いているので，複合語同音異義語䛊りに限ら ず，文字削除䛊りなどの別の夕イプの䛊りに適用することも可能である．さらに本論 文では，本手法の有効性を検証するために行った評価実験の結果についても述べ，意 味的制約を用いた複合語同音異義語誤り検出/訂正支援手法との比較についても述 べる.

キーワード： 日本文推敲支援，同音異義語誤り検出，文字連鎖，テキスト処理，自然言語処理

\section{A Method for Detecting Japanese Homophone Errors in Compound Nouns based on Character Cooccurrence and Its Evaluation}

\author{
MASAhiro $\mathrm{OKU}^{\dagger}$ and KoJI MATSUOKA ${ }^{\dagger}$
}

Most Japanese texts are produced with Japanese word processors. As Japanese texts consist of phonograms, KANA, and ideograms, KANJI, Japanese word processors always use KANA-KANJI conversion in which KANA sequences input through the keyboard are converted into KANA-KANJI sequences. Therefore, Japanese texts suffer from homophone errors caused by erroneous KANA-KANJI conversion. A homophone error occurs when a KANA sequence is converted into the wrong word which has the same reading. Detecting homophone errors is an important topic in Japanese text revision support systems. We have already proposed a high performance method for handling Japanese homophone errors in compound nouns used in REVISE. The method, however, has some drawbacks. To compensate for these drawbacks, this paper describes a method for detecting Japanese homophone errors in compound nouns that uses character cooccurrence. Character cooccurrence can be easily collected from existing texts without any analysis. Therefore, this method can be used, in a Japanese revision support system, as a complementary method for handling Japanese homophone errors in compound nouns. Moreover, as this method depends only on character cooccurrence, it can be applied not only to homophone errors but also other types of errors such as character deletion.

KeyWords: Japanese Proofreading Support System, Homophone Error Detection, Char- 
acter Cooccurrence, Text Processing, Natural Language Processing

\section{1 まえがき}

最近の文書作成はほとんどの場合，日本語ワードプロセッサ（ワープロ）を用いて行われて いる。これに伴い，ワープロ文書中に含まれる誤りを自動的に検出するシステムの研究が行わ れている (福島俊一, 大竹暁子, 大山裕, 首藤友喜 1986; 空閑茂起 1986; 池原悟, 安田恒雄, 島崎 勝美, 高木伸一郎 1987; 鈴木恵美子 cdot 武田浩一 1989; 小原永, 高木伸一郎, 林良彦, 武石英二 1991; 池原悟, 小原永, 高木伸一郎 1993). ワープロの入力方法としては一般にかな漢字変換が用 いられている。このため，ワープロによって作成された文書中には変換ミスに起因する同音異 義語誤りが生じやすい，同音異義語誤りは，所望の単語と同じ読みを持つ別表記の単語へと誤つ て変換してしまう誤りである。従って，同音異義語誤りを自動的に検出する手法を確立するこ とは，文書の誤り検出／訂正作業を支援するシステムにおいて重要な課題の 1 つとなている.

同音異義語誤りを避けたり，同音異義語誤りを検出するために種々の方法が提案されてい る (福島俊一他 1986; 牧野寛 $c d o t$ 木澤誠 1981; 中野洋 1982; 大島義光, 阿部正博, 湯浦克彦, 武 市宣之 1986; 鈴木恵美子 cdot 武田浩一 1989; 田中康仁, 水谷静夫, 吉田将 1984a; 田中康仁 吉 田将 1987)。われわれは, 日本文推敲支援システムREVISE (小原永他 1991) において, 意味 的制約に基づく複合語同音異義語誤りの検出／訂正支援手法を採用している(Oku 1994; 奥雅 博 1996). この手法の基本的な考え方は,「複合語を構成する単語はその隣に来うる単語（隣接 単語）を意味的に制約する」というものである (3 章参照)。しかしながら，この手法において も以下のような問題点があった；

（1）同音異義語ごとに前方／後方隣接単語に対する意味的制約を, 䛊り検出知識及び訂正 支援のための知識として収集しなければならない。しかし，このような意味的制約を人 手を介さずに自動的に収集することは困難である。

（2）検出すべき同音異義語誤りを変更すると，意味的制約を記述した辞書を新たに構築す る必要が生じる。

これらの問題点を解決するためには, 誤り検出知識として収集が容易な情報を使用する必要 がある.この条件に合致する情報の 1 つとして文書中の文字連鎖がある. 文字連鎖の情報は既 存の文書から容易に収集することができる。

3 文字連鎖を用いてかな漢字変換の誤りを減らす手法については (栃内香次, 伊藤太亮, 鈴木 康広 1986) が報告されているが，この手法は漢字をすべて 1 つのキャラクタとして扱っている ため, 複合語に含まれる同音異義語鿁りを検出することができない. また，文字の 2 重マルコ フ連鎖確率を用いて日本文の誤りを検出し，その訂正を支援する手法が提案されている(荒木 哲郎, 池原悟, 塚原信幸 1993)。この手法は,「漢字仮名混じり文節中に誤字または誤挿入の文字 
列が存在するときは，m 重マルコフ連鎖確率が一定区間だけ連続してあるしきい值以下の值を 取る」という仮説に基づいて誤字，脱字及び誤挿入文字列の誤り種別及び位置を検出するもの である，同音異義語誤りは単語単位の誤字と捉えることができるが，この手法が同音異義語鿁 りに対して有効であるか否かについては報告されていない.

一方，日本文推敲支援システム REVISE は，ルールに基づく形態素解析を基本にしたシス テムであり，その中に誤り検出知識として収集が容易な統計的な情報を導入した誤り検出手法 を確立することも重要な課題である，そこで，本論文では，収集が容易な統計的な誤り検出知 識として文字連鎖に焦点をあて，文字連鎖を用いた複合語同音異義語誤りの検出手法について 述べる。さらに，その有効性を検証するために行った評価実験の結果についても述べる.

以下，2 章において本論文で用いる用語の定義を行い，3 章において日本文推敲支援システ ム REVISEにおける誤り検出の流れと，意味的制約に基づく複合語同音異義語誤りの検出手法 の概要及びその問題点について述べる，4 章では，3 章で述べる問題点を解決するために，文字 連鎖を用いて複合語に含まれる同音異義語誤りを検出する手法を提案する．5 章では，本手法 の有効性を評価するために行った同音異義語誤り検定の評価実験について述へ，意味的制約を 用いた同音異義語愦り検出／訂正支援手法との比較を含めた考察を加える.

\section{2 用語の定義}

複合語： 2 つ以上の語が助詞を介さずに複合して成立した語.

○同音語： 読みが同じで意味の異なる 2 つ以上の語の集合と定義する．表 1 に同音語の種類 を示す (大島義光他 1986).

同音異義語集合： 同じ読みを持つ単語を要素とする集合であって，各要素が同品詞であり， かつ表記ゆらぎでないもの（表 1 参照）を同音異義語集合と定義する．例えば“科学” と“化学”は同じ同音異義語集合に属する.

○同音異義語：一般には同音語と同じ意味で用いられるが，本論文では，同音異義語集合の 各要素のことを同音異義語と定義する。単語 $\mathrm{A}$ が単語 $\mathrm{B}$ と同じ読みを持つとき,「単語 $\mathrm{A}$ は同音異義語 $\mathrm{B}$ を持つ」,「単語 $\mathrm{A}$ の同音異義語は Bである」などと表現する.

○同音異義語誤り： ある単語から，それと同じ同音異義語集合に属する単語への置換誤りを 同音異義語誤りと定義する. 表 2 に同音異義語誤りの例を示す.

前方隣接単語, 後方隣接単語, 隣接単語： 複合語において, ある単語の直前に位置する単 語をその単語の前方隣接単語，直後に位置する単語をその単語の後方隣接単語とよぶ. また, 隣接単語とは，前方隣接単語，後方隣接単語のいずれかを指す.

確定単語： ある単語が属する同音異義語集合の要素数が 1 であるとき，すなわち，ある単 語に同音異義語が存在しないとき，この単語を確定単語とよぶ.

不確定単語： ある単語が属する同音異義語集合の要素数が 2 以上であるとき，すなわち， 
表 1 同音語の種類

\begin{tabular}{|c|l|l|}
\hline & 種 類 & \multicolumn{1}{|c|}{ 例 } \\
\hline 同 & 同音異義語 & 科学/化学, 買う/飼う \\
\cline { 2 - 3 } 詞 & 表記ゆらぎ & 行う/行なう/おこなう \\
\hline 異 & 副詞/動詞 & 挙げて/上げて \\
\cline { 2 - 3 } \\
\cline { 3 - 3 }
\end{tabular}

表 2 同音異義語誤りの例

\begin{tabular}{|c|c|c|}
\hline & 種 類 & 例（正解語／誤り語） \\
\hline \multirow{4}{*}{$\begin{array}{l}\text { 同 } \\
\text { 章 } \\
\text { 㭟 } \\
\text { 義 } \\
\text { 語 } \\
\text { 誤 } \\
\text { n }\end{array}$} & 複合語 & 自然科学／自然化学 \\
\hline & 名詞句 & 先進の技術／専心の技術 \\
\hline & 単文 & 野菜を買う/野菜を飼う \\
\hline & 文脈 & $\begin{array}{l}\text { その都市は暑かった } \\
\text { ノその年は暑かった }\end{array}$ \\
\hline
\end{tabular}

ある単語に同音異義語が存在するとき，この単語を不確定単語とよぶ.

○意味属性： 単語をその意味により有限個の概念に写像したもの。例えば，単語 “自然”， “天然”はともに意味属性 [自然] に属する，以降，意味属性を表すのに［］を用いる.

$\bigcirc \mathbf{n}$ 文字連鎖： $\mathrm{n}$ 文字連鎖とは，実文書に現れる $\mathrm{n}$ 文字の並びである．誤りのない大量の文 書から $\mathrm{n}$ 文字の並び（n 文字連鎖）を集めることによって，正しい $\mathrm{n}$ 文字連鎖，すなわ ち，䛊りを検出するための知識を収集することができる.

\section{3 意味的制約に基づく複合語同音異義語誤り検出の概要}

\section{1 日本文推敲支援システム REVISE における位置づけ}

日本文推敲支援システム REVISEの概略フロー図を図 1 に示す. REVISE は，入力された 日本語文書に対して形態素解析処理を行う. 次に経り誤りや助詞抜けなどの誤りを誤り検出知 識を参照して検定し, 発見した誤りに対して訂正候補を提示する. REVISEにおける誤り検出 の基本的な考え方は, 「正しい文に対して高い解析精度を持つ形態素解析を適用したとき, 解析 に失敗した箇所には誤りが含まれている可能性が高い」というものである.しかし, 誤りの種 類によっては形態素解析に成功するものが存在する. 同音異義語誤り, 特に複合語に含まれる 同音異義語誤りはこの種の誤りの 1 つである. REVISEでは，あらかじめ用意しておいた特定 の同音異義語が複合語に含まれるときに 3.2 節で述べる同音異義語誤り検定処理が起動される.

\section{2 処理の概要と問題点}

従来より, ある単語に関係する語は限られており, 特に複合語において隣接する単語の組合 せは限られていることが指摘されている (田中康仁, 水谷静夫, 吉田将 1984b; 田中康仁・吉田将 1987). また, 人間は前後一語の環境があれば, ある単語を認定することができ, 特に複合語に おいてその傾向が顕著であると言われている (中野洋 1982).これらのことは複合語において隣 接する単語間には意味的制約が存在することを示唆している。そこで我々は，複合語において 隣接する単語間に成立する意味的制約に着目して複合語に含まれる同音異義語誤りを榆出する 


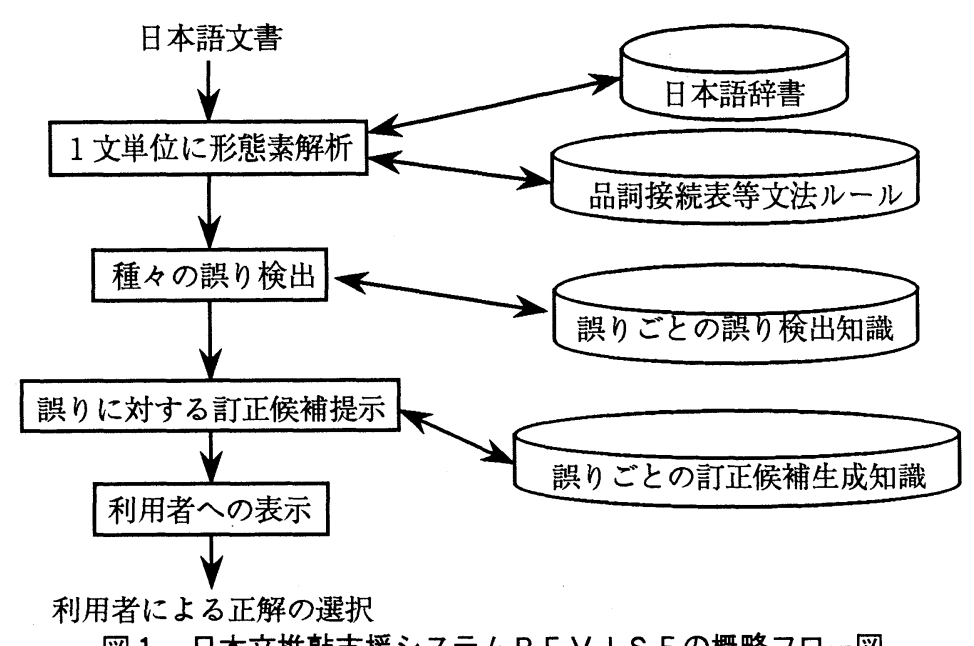

図 1 日本文推敲支援システムR E V I S E の概略フロー図

手法を提案した $(\mathrm{Oku} 1994$; 奥雅博 1996).この手法は，同音異義語とこれに隣接する単語との 間に成立する意味的制約のみを利用して複合語に含まれる同音異義語誤りを検出する，以下に 例を用いてこの手法の概要を述べる.

図 2 に不確定単語 “化学”を含む複合語 “自然化学”における同音異義語誤りの検出／訂正 候補推定の例を示す。ここで, “化学”は同音異義語 “科学”を持つ不確定単語, “自然”は確 定単語とする。なお，“化学”は“科学”のほかに同音異義語を持なないものとする.

不確定単語 “化学” の前方に対する意味的制約を表す意味属性集合を $P S_{1}$, 不確定単語 “科 学”の前方に対する意味的制約を表す意味属性集合を $P S_{2}$ とする．複合語“自然化学”におい て不確定単語 “化学”の前方隣接単語 “自然”の持つ意味属性は [自然] であるが, 図 2 に示 すように不確定単語“化学”の前方に対する意味的制約を表す意味属性集合 $P S_{1}$ は,

[自然 $\notin P S_{1}$

を満足するすなわち，不確定単語“化学”の前方に位置する“自然”は，不確定単語“化学” の持つ前方に対する意味的制約を満足しない。従って, 不確定単語 “化学”を複合語 “自然化 学”において同音異義語誤りとして検出することができる.

次に同音異義語誤り “化学”に対する訂正候補を推定する過程に入る．同音異義語誤り “化学”に対する訂正候補は，その前方に対する意味的制約を表す意味属性集合に意味属性 [自 然）を含んでいなければならない，図 2 より，読み“かがく”を持つ“化学”と同音異義の関係 にある“科学”の意味的制約を表す意味属性集合 $P S_{2}$ は,

$$
\text { [自然 }] \in P S_{2}
$$


を満足するすなわち，“自然”は不確定単語“化学”の同音異義語である“科学”の前方に対 する意味的制約を満足する，従って，“化学”の同音異義語 “科学”を訂正候補として推定し， ユーザに提示することができる.
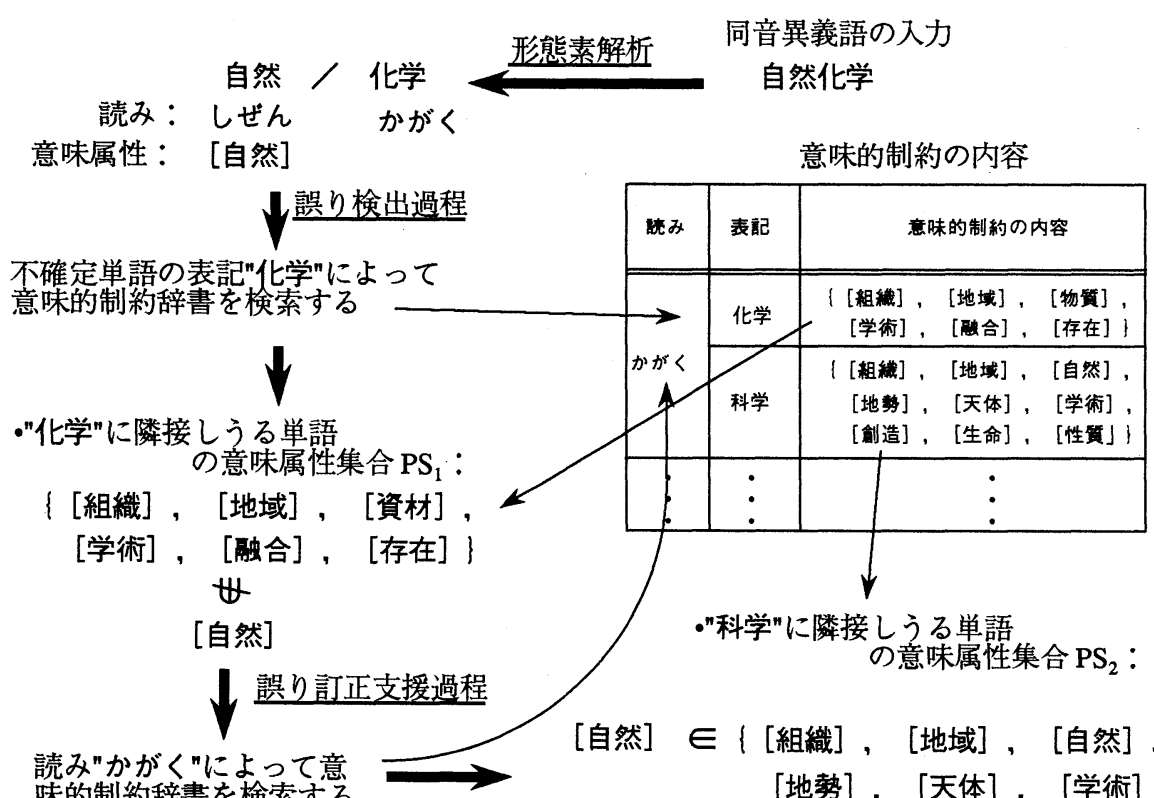

味的制約辞書を検索する

[自然 $] \in\{$ [組織]，[地域 $] ，[$ 自然 $]$ ， [地勢]，[天体]，[学術]， [創造］，［生命］，［性質］\}

$\therefore$ "科学"を同音異義語誤り"化学"の訂正候補 としてユーザに提示。

図 2 同音異義語誤り処理の例

しかしながら，この手法には以下のような問題点が存在する；

（1）同音異義語ごとに前方／後方隣接単語に対する意味的制約を，誤り検出／訂正支援知 識としてあらかじめ収集しておかなければならない。しかし，このような意味的制約を 人手を介さずに自動的に収集することは困難である。すなわち，誤り検出／訂正支援知 識の収集に大きな工数を要する.

（２）検出すべき同音異義語誤りを变更すると，意味的制約を記述した辞書を新たに構築す る必要が生じる。

\section{4 文字連鎖を用いた複合語同音異義語誤り検出手法の提案}

3.2 節で述べた問題点を解決するために，本論文では誤り検出知識として収集が容易な情報 である文字連鎖を用いた手法について提案する。 


\section{1 基本的な考元方}

日本文推敲支援システムREVISE は，ルールベースの形態素解析によって複合語を単語単 位に分割するので，その単語間の結びつきを見るには文字や単語の連鎖確率ではなく，連鎖そ のものを調べればよい1．また，単語連鎖を収集するには，䛊り検出知識の収集の段階で，形態 素解析を大量の文書に対して正確に行わなければならず，䛊り検出知識を容易に収集するとい う目的に反する。一方，文字連鎖は，大量の文書から機械的にかつ容易に収集することができ る．以上のことから，本論文で述べる文字連鎖を用いた複合語同音異義語䛊りの検出手法の基 本的な考え方は, 「既存の文書に現れている $\mathrm{n}$ 文字連鎖をあらかじめ大量に集めておき, 検定対 象の不確定単語を含む $\mathrm{n}$ 文字連鎖がその中に含まれているかを検証することにより, 検定対象 の不確定単語が誤りか否かを判定する」というものである.

図 3 に不確定単語を含む複合語に対して，どの部分の $\mathrm{n}$ 文字連鎖を誤り検出に用いるかを模 式的に示す，複合語中で不確定単語に前方隣接単語が存在する場合には, 不確定単語の先頭か ら (n-i) 文字と前方隣接単語の末尾 $\mathrm{i}$ 文字とから構成される $\mathrm{n}$ 文字連鎖を用いて検定を行う. 複 合語中で不確定単語に後方隣接単語が存在する場合には, 不確定単語の末尾から (n-i) 文字と後 方隣接単語の先頭 $\mathrm{i}$ 文字とから構成される $\mathrm{n}$ 文字連鎖を用いて検定を行う。

複合語

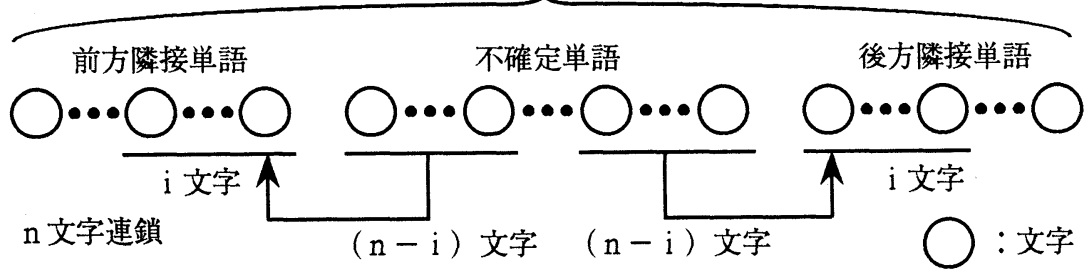

不確定単語が正しい同音異義語であれば，上記の $\mathrm{n}$ 文字連鎖が

あらかじめ収集した n文字連鎖辞書に存在する。

図 3 文字連鎖を用いた同音異義語誤り検出の基本的な考え方

\section{2 処理の流れ}

図 4 に $\mathrm{n}$ 文字連鎖を用いた同音異義語誤り検出の概略フローを示す。ここで，複合語の範囲 および単語への分割は，困 1 に示した形態素解析処理の段階で既に行われているものとする.

最初に，入力された複合語が検定対象の不確定単語を含むか否かを調べる．次に，検定対象 の不確定単語を含む場合には，不確定単語の先頭 (n-i) 文字とその前方隣接単語の末尾 i 文字あ 
るいは不確定単語の末尾 $(\mathrm{n}-\mathrm{i})$ 文字とその後方隣接単語の先頭 $\mathrm{i}$ 文字とから $\mathrm{n}$ 文字連鎖を作成し, この $\mathrm{n}$ 文字連鎖があらかじめ収集してある $\mathrm{n}$ 文字連鎖辞書に存在するか否かを調べる，存在す れば着目している不確定単語は正しく使用されていると判定し，存在しない場合にはその不確 定単語を同音異義語誤りであると判定する。

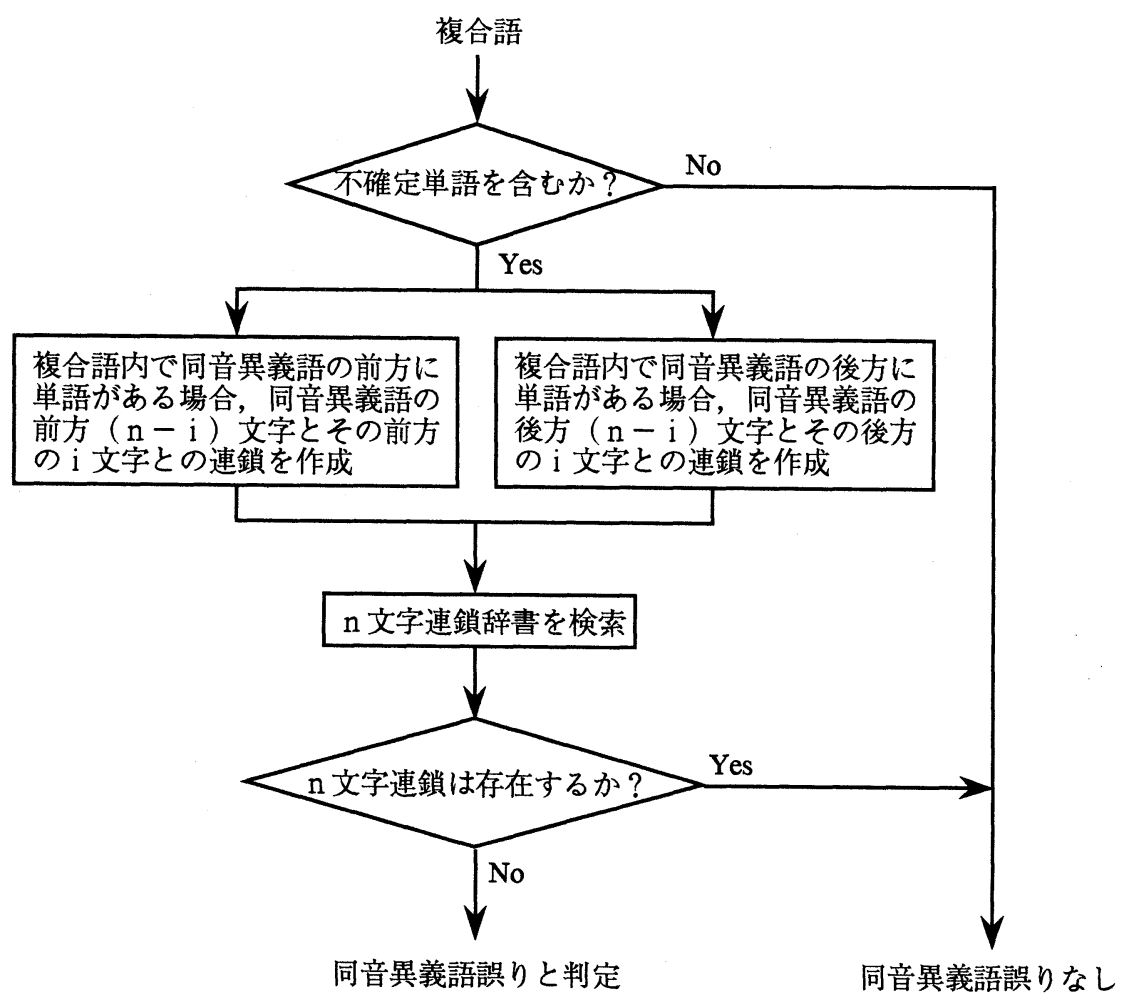

図 4 文字連鎖を用いた同音異義語誤り検出の概略フロー図

\section{5 評価実験}

本手法の有効性を確認するために同音異義語誤り検出の評価実験を行った。なお，入力とな る複合語はすでに形態素解析処理により構成単語は既知となっているものとする.

\section{1 文字連鎖辞書の作成}

$\mathrm{n}$ 文字連鎖辞書としては，2 文字連鎖辞書 $(\mathrm{n}=2, \mathrm{i}=1)$ と 3 文字連鎖辞書 $(\mathrm{n}=3, \mathrm{i}=1)$ を用意 して, 誤り検出の精度という観点から両者の比較を行う。さらに，辞書の大きさ，すなわち文 字連鎖の収集度合いによる誤り検出の変化を調べるために，それぞれ 3 種類の 2 文字連鎖辞書， 
3 文字連鎖辞書を用意した。表 3 に評価実験に用いた 6 種類の文字連鎖辞書の概要を示す。な お，これらの辞書はすべて新聞記事から作成した。

誤り検出の知識として長い文字連鎖を用いる方が誤りの検出精度が高くなることが予想され るが, 反面，正しいものまで誤りとして検出してしまう可能性も同時に高くなると考えられる. 2 文字連鎖辞書と 3 文字連鎖辞書とを用いた実験を行うことにより，このような傾向についても 考察することができる.

表 3 文字連鎖辞書の概要

\begin{tabular}{|c|c|c|}
\hline 名称 & 見出し数 & 概要 \\
\hline 2 文字連鎖辞書 1 & 64,045 & $\begin{array}{l}15 \text { 日分の新聞記事から } 2 \text { 回以上現れた } \\
2 \text { 文字連鎖を収集 }\end{array}$ \\
\hline 2 文字連鎖辞書 2 & 111,037 & $\begin{array}{l}15 \text { 日分の新聞記事から } 1 \text { 回以上現れた } \\
2 \text { 文字連鎖を収集 }\end{array}$ \\
\hline 2 文字連鎖辞書 3 & 205,992 & $\begin{array}{l}60 \text { 日分の新聞記事から } 1 \text { 回以上現れた } \\
2 \text { 文字連鎖を収集 }\end{array}$ \\
\hline 3 文字連鎖辞書 1 & 159,933 & $\begin{array}{l}15 \text { 日分の新聞記事から } 2 \text { 回以上現れた } \\
3 \text { 文字連鎖を収集 }\end{array}$ \\
\hline 3 文字連鎖辞書 2 & 453,418 & $\begin{array}{l}15 \text { 日分の新聞記事から } 1 \text { 回以上現れた } \\
3 \text { 文字連鎖を収集 }\end{array}$ \\
\hline 3 文字連鎖辞書 3 & $1,134,736$ & $\begin{array}{l}60 \text { 日分の新聞記事から } 1 \text { 回以上現れた } \\
3 \text { 文字連鎖を収集 }\end{array}$ \\
\hline
\end{tabular}

\section{2 評価実験 1}

評価実験 1 では正しく使用されている不確定単語を $\mathrm{n}$ 文字連鎖によってどの程度正しいと判 定できるかを調べた。

\subsection{1 評価実験 1 に用いた評価用データ}

○評価実験に用いた不確定単語

表 4 に評価実験に用いた 23 個の同音異義語集合とこれらに含まれる同音異義語 77 語を 示す.

○評価実験 1 に用いた複合語正解データ

表 5 に評価実験に用いた複合語データの概要を示す。高校の教科書および新聞記事にお いて，表 4 に示した同音異義語のいずれかを含む複合語を抽出し，それぞれデー夕 1 , データ 2 とした。なお，データ 2 を抽出した新聞記事は 5.1 節で述べた文字連鎖辞書を 作成した新聞記事とは異なる 2 .

2 デー夕 1 を用いた評価実験は，文字連鎖辞書を作成した文書（新聞記事）と異なる分野の文書（教科書）に対して行う ものであり，デー夕も分野もオープンという性格を持つ。また，デー夕 2 を用いた評価実験は，文字連鎖辞書と同じ分 
表 4 評価実験に用いた同音異義語

\begin{tabular}{|c|c|c|c|c|c|c|c|c|c|c|c|}
\hline 読み & \multicolumn{5}{|c|}{ 同音異義語の表記 } & 読み & \multicolumn{5}{|c|}{ 同音異義語の表記 } \\
\hline かがく & 化学 & 科学 & & & & しょうがく & 小額 & 少額 & 奨学 & 商学 & 小学 \\
\hline かこう & 加工 & 下降 & 火口 & 河口 & & しょうきゃく & 焼却 & 償却 & 消却 & & \\
\hline きかい & 機械 & 器械 & 機会 & & & しょめい & 署名 & 書名 & & & \\
\hline きせい & 㫶省 & 寄生 & 規制 & 既製 & 既成 & じてん & 辞典 & 字典 & 事典 & & \\
\hline & 替正 & 規整 & & & & せん & 先進 & 専心 & & & \\
\hline きょうこう & 強硬 & 強行 & 恐慌 & 凶行 & 兇行 & ちか & 地下 & 地価 & & & \\
\hline きょうそう & 競争 & 競走 & 強壮 & 狂騒 & 狂想 & ていがく & 定額 & 低額 & 停学 & & \\
\hline げんか & 原価 & 減価 & & & & でんき & 電気 & 電機 & 電器 & 伝記 & 伝奇 \\
\hline こうぎょう & 工業 & 鉱業 & 鋼業 & 與業 & 興行 & ないぞう & 内臓 & 内藏 & & & \\
\hline こうたい & 交代 & 後退 & 交替 & 抗体 & & にほん & 日本 & 二本 & & & \\
\hline さいてい & 最低 & 裁定 & & & & ふよう & 不要 & 扶養 & 不用 & 不溶 & \\
\hline してん & 支店 & 視点 & 支点 & & & ほけん & 保険 & 保健 & & & \\
\hline
\end{tabular}

表 5 評価用複合語データの概要

\begin{tabular}{|c|c|c|c|}
\hline データの種類 & データ名 & 件数 & 概要 \\
\hline \multirow{2}{*}{ 複合語正解データ } & データ 1 & 60 & 高校の教科書から抽出した複合語 \\
\hline & データ 2 & 449 & 新聞記事から抽出した複合語 \\
\hline 複合語誤りデータ & データ 3 & 242 & $\begin{array}{l}\text { データ } 1 \text { に含まれる不確定単語を } \\
\text { 表 } 4 \text { に示す同音異義語に置き換え } \\
\text { た同音異義語誤りを含む複合語 }\end{array}$ \\
\hline
\end{tabular}

\section{3 評価実験 2}

評価実験 2 では, 詥った不確定単語を含む複合語を用意し， $\mathrm{n}$ 文字連鎖によってどの程度䛊 りを検出できるのかを調べた，本論文では，同音異義語集合を前記の表 4 に示すものに限定し， 評価用の複合語誤りデー夕を作成した ${ }^{3}$.

\subsection{1 評価実験 2 に用いた評価用データ}

○評価実験 2 に用いた複合語誤りデータ

表 5 に示すように，複合語正解データに含まれる不確定単語をその同音異義語で置き換 えることによって複合語誤りデータ（データ 3）を作成した，元とした複合語正解デー 夕は評価実験 1 で用いた教科書から抽出した複合語正解データ（デー夕 1）である.

野 (新聞記事) であるが，異なる文書に対して行うものであり，分野はクローズであるがデー夕はオープンという性格 を持つ。

3 本来，表 4 に示す 23 個の同音異義語集合に属する同音異義語 77 語だけでなく，同じ読みを持つ同音異義語すべてを対 象に評価実験を行うべきであろう。しかし，表 4 に示すもの以外の表記を持つ同音異義語の出現頻度は低いため，今回 の評価実験ではこのような限定を設けた。 


\section{4 実験方法}

\subsection{1 正解／誤りの判定}

2 文字連鎖辞書を用いる場合，不確定単語が複合語の先頭にあるときには，その不確定単語 の末尾 1 文字とその後方隣接単語の先頭 1 文字とから 2 文字連鎖を作成する. 不確定単語が複 合語の末尾にあるときにはその不確定単語の先頭 1 文字とその前方隣接単語の末尾 1 文字とか ら 2 文字連鎖を作成する。そして，これらの 2 文字連鎖をキーとして 2 文字連鎖辞書を検索す る。また， 3 文字連鎖辞書を用いる場合，不確定単語が複合語の先頭にあるときには，その不確 定単語の末尾 2 文字とその後方隣接単語の先頭 1 文字とから 3 文字連鎖を作成する. 不確定単 語が複合語の末尾にあるときにはその不確定単語の先頭 2 文字とその前方隣接単語の末尾 1 文 字とから 3 文字連鎖を作成する。そして，これらの 3 文字連鎖をキーとして 3 文字連鎖辞書を 検索する. 検索の結果, 前記の 2 (または 3) 文字連鎖が存在すれば不確定単語は正しく使用さ れている (正解) と判定し，存在しない場合には同音異義語誤りであると判定する．なお，不 確定単語が複合語の中間に位置するときには，両方の 2 （または $3 ）$ 文字連鎖を調べ，どちらか 一方でも2（または 3) 文字連鎖辞書に存在すれば正解と判定する.

\subsection{2実験結果を評価するための指標}

本論文では，実験結果を以下の 2 つの指標を用いて表現する.

（1）正解指摘率：正解語を正しいと指摘できる能力を示す指標；評価実験 1 の結果を表す のに用いる。

$$
\text { ○正解指摘率 }=\frac{\text { 正解と判定できた件数 }}{\text { 正解データの全件数 }}
$$

（2）鿁り検出率：誤り語を誤りとして検出できる能力を示す指標；評価実験 2 の結果を表 すのに用いる。

$$
\text { ○誤り検出率 }=\frac{\text { 䛊りとして検出した件数 }}{\text { 誤りデータの全件数 }}
$$

\subsection{3 実験結果}

評価実験 1 ，評価実験 2 の結果を表 6 および図 5 , 図 6 に示す.

\section{評価実験 1 の結果}

表 6 および図 5 , 図 6 より以下のことが分かる;

（1） 2 文字連鎖辞書を用いた場合には，3 文字連鎖辞書を用いた場合に比較して正解指摘 率は 6 ～15\%程度高い. また，この差は辞書サイズが大きくなるにつれて小さくなる.

（2）正解指摘率は辞書の大きさに依存して，2 文字連鎖辞書を用いた場合には $40 \sim 83 \%$ の 間で，3 文字連鎖辞書を用いた場合には $27 \sim 77 \%$ の間で大幅に変動しているが，辞書サ イズを大きくするにつれて正解指摘率は向上する. 
（３）文字連鎖辞書と同一の分野である新聞記事を対象とした場合（デー夕2）の方が，教 科書を対象とした場合（データ 1）に比較して 15３0\%程度高い值を示しており，誤り 検出における分野依存性が見られる。

（4）䛊り検出知識である文字連鎖を収集する分野と同一分野の文書を対象とすると，3文 字連鎖辞書 3 の場合で正解指摘率 $=77 \%$ となり，意味的制約を用いた手法 (奥雅博 1996) と同等の能力を有している.

（5）文字連鎖辞書 1 を用いた場合と文字連鎖辞書 2 を用いた場合とを比較すると，2文字 連鎖，3 文字連鎖ともに文字連鎖辞書 2 を用いた場合の方が高い正解指摘率を示してい る.このことは，既存の文書に 1 回でもその文字連鎖が現れれば正解とすべきであるこ とを示している4.

\section{評価実験 2 の結果}

評価実験 2 の結果を示した表 6 および図 5 ，図 6 より以下のことが分かる；

（1）3 文字連鎖辞書を用いた場合には，2 文字連鎖辞書を用いた場合に比較して誤り検出 率は $21 \sim 34 \%$ 程度高い. また，この差は辞書サイズが大きくなるほど，大きくなってい る。すなわち，2 文字連鎖辞書を用いた場合には，辞書サイズが大きくなるほど誤り検 出率が急激に悪くなることを示している.

（2）誤り検出率は辞書の大きさに依存して，2 文字連鎖辞書を用いた場合には 60 ～78\%の 間で，3 文字連鎖辞書を用いた場合には 94 99\%の間で変動しているが，辞書サイズを 大きくするにつれて誤り検出率は徐々に減少する。また，この減少割合は正解指摘率の 増加割合に比較して緩やかである。

（３）データ 3 は教科書から作成したものであり，文字連鎖辞書を作成した分野 (新聞記事) とは異なる．しかし，分野が異なるにも関わらず，どの 3 文字連鎖辞書でも $90 \%$ 以上の 誤り検出率が得られている.

\section{4 .4 考察}

\section{○文字連鎖を用いた複合語同音異義語誤り検出手法のポテンシャル}

上記の結果から，2 文字連鎖辞書を用いた場合には，3 文字連鎖辞書を用いた場合に比較し て，正解指摘率が高く，誤り検出率が低いことが分かる．推敲支援という目的を考えれば，2文 字連鎖辞書を用いた場合の誤り検出率が 60 ～78\%というのは低すぎると考えられる。これに対 して 3 文字連鎖辞書を用いた場合には辞書サイズにかかわらず，90\%以上の誤り検出率が得ら れている．また，正解指摘率で見な場合，確かに 2 文字連鎖辞書を用いた方が 3 文字連鎖辞書 を用いた場合に比べて高い值を示しているが，辞書サイズを大きくするとその差は $6 \%$ 程度と非

4 文字連鎖辞書 1 と文字連鎖辞書 2 とは同じ量の新聞記事から作成した（表 3 参照）。異なるのは文字連鎖辞書 1 が 2 回 以上現れた文字連鎖のみをカウントしているのに対して，文字連鎖辞書 2 は 1 度でも現れた文字連鎖をカウントしてい る点のみである。 
表 6 実験結果

\begin{tabular}{|c|c|c|c|}
\hline \multirow{2}{*}{} & \multicolumn{2}{|c|}{ 正解指摘率 [\%] } & 誤り検出率 [\%] \\
\cline { 2 - 4 } & データ 1 & データ 2 & データ 3 \\
\hline 2 文字連鎖辞書 1 & 40.0 & 53.2 & 78.1 \\
\hline 2 文字連鎖辞書 2 & 48.3 & 64.8 & 69.8 \\
\hline 2 文字連鎖辞書 3 & 63.3 & 83.1 & 60.3 \\
\hline 3 文字連鎖辞書 1 & 26.7 & 43.7 & 99.2 \\
\hline 3 文字連鎖辞書 2 & 35.0 & 57.7 & 95.9 \\
\hline 3 文字連鎖辞書 3 & 48.3 & 77.1 & 94.2 \\
\hline
\end{tabular}

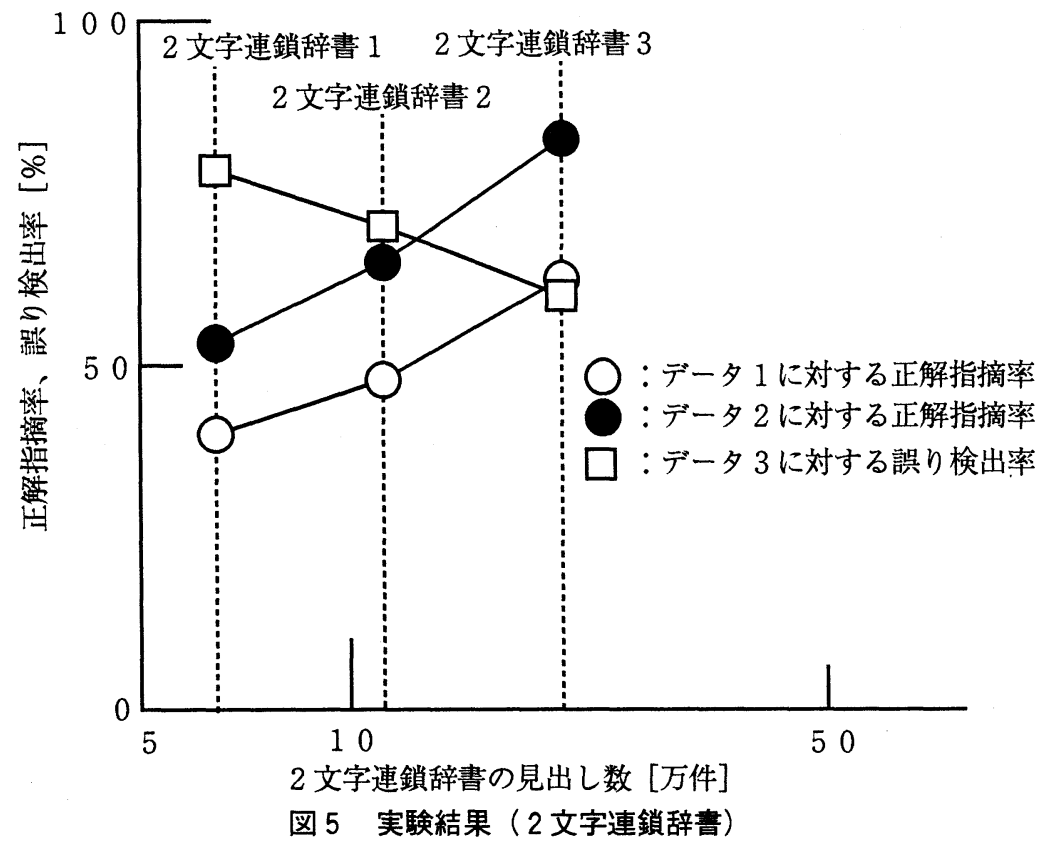

常に小さくなる，すなわち，推敲支援という目的に使用するには，2 文字連鎖よりも 3 文字連 鎖を誤り検出知識として用いる方がよいと言える.

3 文字連鎖辞書による検定の方が 2 文字連鎖辞書による検定よりも優れている理由の 1 つと して次のことが考えられる。

多くの単語は 2 文字 (特に 2 漢字) から構成されているため, 3 文字連鎖はこれらの単語と その前後 1 文字との連鎖を表すことになる.すなわち，単語そのものとその前後の文字との連 鎖として 3 文字連鎖を近似的にとらえることができるためである．従って，さらに文字連鎖の 


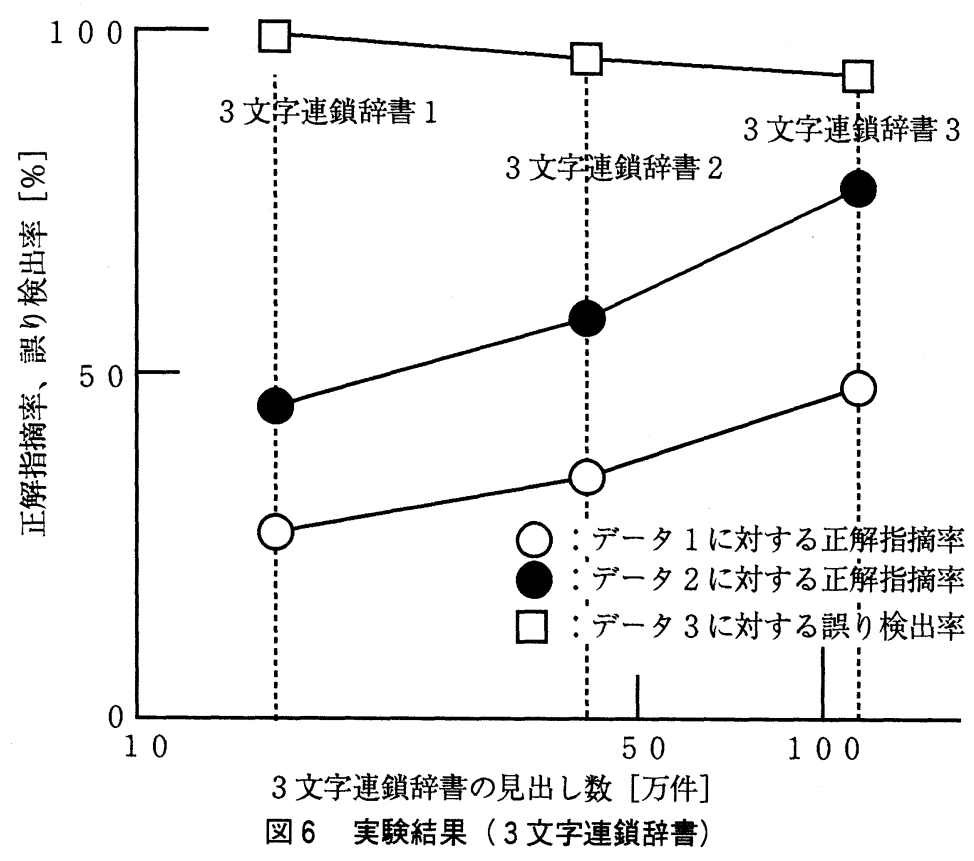

長さを長くしても，必要な連鎖を集める文書量が大幅に増えるだけで，誤り検出率や正解指摘 率の向上はあまり望めないと考えられる。

次に 3 文字連鎖辞書を用いた場合，意味的制約を用いた複合語同音異義語誤りの検出手法と 同程度の精度となる, 誤り検出率 $90 \%$, 正解指摘率 $70 \%$ のとき辞書サイズの概算を行う。困 6 の誤り検出率と正解指摘率を簡単に直線近似すると, 求める辞書サイズは約 250 万件となる. 概算すると 1 年分の新聞記事から 3 文字連鎖辞書を作成すればこの辞書サイズを得ることができ る. 3 文字連鎖の収集の容易さから考えて，1 年分の新聞記事から辞書を作成することは，実現 性の上からも問題はない。すなわち，3文字連鎖辞書を用いた複合語同音異義語誤り検出手法に よって，意味的制約を用いたそれと同程度の精度を実現することが可能であろうと推定できる.

以上のことから，3文字連鎖辞書を誤り検出の知識として用いれば，誤り検出率 $90 \%$ 以上 が得られ，しかも，3 文字連鎖辞書と検定対象デー夕とが同一の分野であれば，正解指摘率も $70 \%$ 以上高い值を示す. また，意味的制約を用いた複合語同音異義語誤りの検出手法と同程 度の精度を得ることも可能であると予測される。すなわち，本論文で提案した文字連鎖を用い た複合語同音異義語誤りの検出手法は, 検定対象の文書の分野を限定し, その分野において 3 文字連鎖辞書を収集することによって，日本文推敲支援システムにおける複合語同音異義語誤 りの検出手法として十分に利用することが可能であると言える. 
表 7 意味的制約を用いた手法と文字連鎖を用いた手法との比較

\begin{tabular}{|c|c|c|}
\hline & 意味的制約を用いた手法 & 文字連鎖を用いた手法 \\
\hline 長所 & $\begin{array}{l}\text { 同音異義語誤りの検出知識として } \\
\text { の意味制約辞書の大きさが小さく } \\
\text { て済む.. } \\
\text { ○誤り検出率が高い. } \\
\text { ○誤検出が少ない. } \\
\text { ○検出した誤りに対する訂正候補を } \\
\text { 提示することができる. }\end{array}$ & $\begin{array}{l}\text { ○文字連鎖辞書を作成するのが非常に } \\
\text { 容易である. } \\
\text { ○検出対象とする同音異義語の変更, } \\
\text { 増加に対して容易に適応することが } \\
\text { できる. }\end{array}$ \\
\hline 短所 & $\begin{array}{c}\text { 意味制約辞書を作成するために, } \\
\text { 多くの時間と労力が必要である. }\end{array}$ & $\begin{array}{c}\text { 十分な誤り検出率を得るためには文 } \\
\text { 字連鎖辞書が大きくなる. } \\
\text { 分野依存性が認められる. }\end{array}$ \\
\hline
\end{tabular}

\section{○本文推敲支援システムへの適用形態}

表 7 に本手法と意味的制約を用いた手法との長所と短所を示す。意味的制約を用いた手法は 高精度の同音異義語誤りの検出と訂正候補の提示が可能であり, 分野依存性が小さい反面, 意 味的制約辞書すなわち誤りを検出するための知識の収集が容易ではない.これに対して，本論 文で提案した手法において䛊り検出知識として利用する 3 文字連鎖は, 既存の文書から容易に 収集することができる。

従って，日本文推敲支援システムにおいては，高頻度の同音異義語愦りに対しては意味的制 約を用いた手法により検出／訂正支援を行い，それ以外の幅広い範囲の同音異義語誤りに対し ては本論文で述べた 3 文字連鎖を用いた手法によって誤りを検出するといった，両手法を統合 した利用形態が望ましいと考えられる。

\section{6 むすび}

本論文では誤り検出知識として文字連鎖を用いた複合語同音異義語誤りの検出手法について 述べた．評価実験の結果，3文字連鎖辞書を誤り検出知識として用いれば，分野依存性はある ものの，3 文字連鎖を収集した分野と同一の分野に属する文書に対しては，誤り検出率 $90 \%$ 以 上，正解指摘率 $70 \%$ 以上の值が得られた．このことは，本論文で提案した文字連鎖を用いた複 合語同音異義語誤りの検出手法は, 検定対象の文書の分野を限定し，その分野において 3 文字 連鎖辞書を収集することによって，日本文推敲支援システムにおける複合語同音異義語誤りの 検出手法として十分に利用することが可能であることを示している.

本論文では 3 文字連鎖によって複合語同音異義語誤りの検出が高精度で可能であることを述 べたが，3文字連鎖を用いれば，他の種類の誤り，例えば文字脱落を検出することも可能であ る (松岡浩司 $c d o t$ 高木伸一郎 1989). 


\section{謝辞}

本研究の遂行にあたり，有益な討論，助言を頂いた高木伸一郎氏，島崎勝美氏の両氏に深謝 致します.

\section{参考文献}

荒木哲郎, 池原悟, 塚原信幸 (1993)。“2 重マルコフモデルによる日本語文の誤り検出並びに訂正 法.”自然言語処理研究会, 情報処理学会 97-5.

池原悟, 小原永，高木伸一郎 (1993)。“文書校正支援システムにおける自然言語処理.”情報処理， $34(10)$.

池原悟, 安田恒雄, 島崎勝美, 高木伸一郎 (1987). “日本文訂正支援システム (REVISE).” 研究 実用化報告, 36 (9).

Oku, M. (1994). "Handling Japanese Homophone Errors in Revision Support System; RE-

VISE." In Proceedings of 4th Conference on Applied Natural Language Processing (ANLP-94), Vol. 1, pp. 156-161.

奥雅博 (1996). “日本文推敲支援システムREVISE における複合語同音異義語誤りの検出およ び訂正支援手法.”電子情報通信学会論文誌, JD79-DII (11).

小原永, 高木伸一郎, 林良彦, 武石英二 (1991). “日本文推敲支援技術.” NTT RED 40 (7). 大島義光, 阿部正博, 湯浦克彦, 武市宣之 (1986). “格文法による仮名漢字变換の多義解消.”情 報処理学会論文誌, $27(7)$.

空閑茂起 (1986). “文書作成・校正支援システム WISE.”テクニカル・レポート，電子情報通信 学会 86-28.

鈴木恵美子・武田浩一 (1989). “日本語文書校正支援システム CRITAC.”情報処理学会論文誌, 30 (11).

田中康仁, 水谷静夫, 吉田将 (1984a). “語と語の関係について.”自然言語処理研究会, 情報処理 学会 41-4.

田中康仁, 水谷静夫, 吉田将 (1984b). “語と語の関係による知識データの収集.”第 21 回情報科 学技術研究集会論文集.

田中康仁 吉田将 (1987). “知識デー夕（語と語の関係）による多義性の解消.” 自然言語処理研 究会, 情報処理学会 60-3.

杤内香次, 伊藤太亮, 鈴木康広 (1986). “漢字連接文字を利用した同音語選択機能を有するかな

漢字変換システム.”情報処理学会論文誌, 27 (3).

中野洋 (1982). “同音語の判別.” 自然言語処理研究会, 情報処理学会 33-4.

福島俊一, 大竹暁子, 大山裕, 首藤友喜 (1986). “日本語文書作成支援システム COMET.”テク ニカル・レポート, 電子情報通信学会 OS86-21. 
牧野寛・木澤誠 (1981). “べた書き文の仮名漢字変換システムとその同音語処理.”情報処理学 会論文誌, 22 (1).

松岡浩司・高木伸一郎 (1989). “連接確率を用いた誤字訂正法.”電子情報通信学会総合大会論 文集, p. D306.

\section{略歴}

奥 雅博: 1982 年大阪府立大学工学部電子工学科卒業. 1984 年同大学院博士前 期課程修了. 同年, 日本電信電話公社 (現 NTT) 入社. 現在, NTT 情報通信 研究所主任研究員. 自然言語処理の研究実用化に従事. 慣用表現, 比喻など の非標準的な言語現象に興味を持つ，情報処理学会，電子情報通信学会，人 工知能学会各会員.

松岡 浩司: 1979 年九州大学電子工学科卒業. 同年, 日本電信電話公社 (現 NTT) 入社. 現在, NTT 情報通信研究所主任研究員. 自然言語処理の研究実 用化に従事. 推敲支援、音声合成などの形態素解析を応用したシステムに興 味を持つ. 情報処理学会, 電子情報通信学会各会員.

(1996 年 12 月 27 日 受付)

(1997 年 3 月 27 日 採録) 